\title{
Notes on distribution of Simulium damnosum s. I. along Atbara River in Galabat sub-focus, eastern Sudan
}

\author{
Isam M. A. Zarroug ${ }^{1 *}$, Arwa Elaagip ${ }^{2}$, Suhaib G. Gumaa ${ }^{3}$, Altayeb K. Ali ${ }^{4}$, Ayman Ahmed ${ }^{5}$, Hanaa A. M. Siam², \\ Deena M. Abdelgadir ${ }^{6}$, Olabanji A. Surakat ${ }^{7}$, Olatunwa J. Olamiju ${ }^{8}$, Daniel A. Boakye ${ }^{9}$, Nabil Aziz ${ }^{10}$ and \\ Kamal Hashim ${ }^{11}$
}

\begin{abstract}
Background: Onchocerciasis is caused by a nematode worm Onchocerca volvulus, which is transmitted in Sudan by black fly vectors of the Simulium damnosum sensu lato species complex. In Sudan, the disease is found in four foci where fast flowing rivers provide suitable breeding sites for the Simulium vector flies. The construction of dams and irrigation schemes for agricultural purposes has affected black fly breeding and distribution, such as in Merowe Dam in Abu-Hamed focus, where the perennially flowing water downstream of the Dam created new vector breeding sites, thereby, changing the pattern of disease transmission and creating public health problems. Based on this situation, this study was carried out to measure the effect of the Upper Atbara and Setit Dam complex on the distribution of Simulium damnosum s.l. breeding sites and on disease elimination in the Galabat sub-focus in eastern Sudan.
\end{abstract}

Methods: Aquatic stages of Simulium were collected between October and November 2009, prior to the construction of the dam complex, and again in 2013 and 2015 while the dam complex construction was ongoing.

Results: A total of 40 breeding sites were identified at the beginning of the study. After the construction of the dam complex in 2015, seventeen previously mapped breeding sites were inaccessible as they had been flooded by the dam complex's lake when reach its maximum size. Three species were obtained from different locations: $S$. damnosum s.l., S. griseicolle, and S. adersi.

Conclusions: This study has shown a link between the construction of the dam complex and a reduction in the breeding sites of black fly vectors. This reduction has limited the Galabat sub-focus to a small area at the upper Atbara River which become the end of the focus. To sustain the success achieved in onchocerciasis control in the Galabat sub-focus, disease control and its vector control should be strengthened in the area cross-boarding Sudan and Ethiopia.

Keywords: Upper Atbara dam, Setit dam, Dam complex, Simulium damnosum s.l., Distribution, Cross-border, Galabat sub-focus, Eastern Sudan

\footnotetext{
* Correspondence: imazarroug@gmail.com

${ }^{1}$ Onchocerciasis Control/Elimination Programme, National Programme for

Prevention of Blindness (NPPB), Federal Ministry of Health, Khartoum, Sudan

Full list of author information is available at the end of the article
}

(c) The Author(s). 2019 Open Access This article is distributed under the terms of the Creative Commons Attribution 4.0 International License (http://creativecommons.org/licenses/by/4.0/), which permits unrestricted use, distribution, and reproduction in any medium, provided you give appropriate credit to the original author(s) and the source, provide a link to the Creative Commons license, and indicate if changes were made. The Creative Commons Public Domain Dedication waiver (http://creativecommons.org/publicdomain/zero/1.0/) applies to the data made available in this article, unless otherwise stated. 


\section{Background}

The River Nile is the longest river in the world [1]. The White Nile contributes a small amount to the annual flow discharge of the River Nile, but flows constantly throughout the year. The Blue Nile and its tributaries contribute by high amount of annual flow but on a highly seasonal basis [1,2]. Although the River Nile is the main source of water in Sudan, the River Atbara and its tributaries are of most importance as seasonal water streams, creating distinct environment for local communities in eastern states [1].

A recent construction began on the Upper Atbara and Setit Dam complex $[1,2]$. This is a twin dam consisting of Rumela Dam on the Upper Atbara River and Burdana Dam on the Setit River in eastern Sudan. The dams are located about $20 \mathrm{~km}$ upstream from the junction of the Atbara and Setit rivers and about $80 \mathrm{~km}$ to the south of Khashm El-Girba Dam [1]. The project began in 2010 and was finished in beginning of 2015. The two connected dams have a joined reservoir. Their total length is $13 \mathrm{~km}$ [3].

Black flies constitute a serious public health problem as vectors of human onchocerciasis and as a biting nuisance in many rural parts of the world $[4,5]$. They breed in rivers in a constant flow of fast-moving water where they attach to rocks and plants and filter out suspended particles $[5,6]$. Some human structures such as concrete dams and concrete-lined stream channels provide excellent developmental sites for larvae and pupae of black fly species. This may result in adverse environmental and health impacts, which may extend to other countries, as in the case of the River Nile $[5,7,8]$.

In Sudan, human onchocerciasis is currently known in four main foci: Abu-Hamed in northern Sudan, Galabat in eastern Sudan, Radom in southern Darfur in the southwest, and Khor Yabus in Blue Nile region of the southeast [5]. Few studies have addressed the impact of dams on transmission dynamics of onchocerciasis in African countries $[4,9-12]$. It has been suggested that onchocerciasis is the major environmental health problem around other dams in Africa [5, 9, 13]. In Sudan, few studies have highlighted the impact of dams on transmission dynamics of onchocerciasis. Biting activity of black flies was reported near Meridi and Roseires Dams, indicating that dam construction may affect the dynamics and extent of onchocerciasis transmission [14, 15]. Additionally, larvae of $S$. damnsosum s.l. were found in the spillways of Khashm El-Girba Dam after its construction [16]. Currently, Merowe Dam in Abu-Hamed focus has effectively shrunken the focus to a little over half of its original size and eliminated black fly breeding sites west to the town of Abu-Hamed [5].

The Galabat sub-focus is located along the banks of Atbara River and extends to the Ethiopian land in the
Metema sub-focus [17, 18]. It has been recommended that any vector control activities based in this area would be operated by the Sudanese and Ethiopian governments [17]. Galabat started full continuous annual community- directed treatment with ivermectin (CDTI) in 2007. The prevalence of microfilariae was determined in a previous survey as $63.4 \%$ associated with a remarkable degree of pruritus and onchodermatitis [19]. The corresponding black fly infectivity rate in Galabat was 6.9/10,000 flies (95\% CI = 1.1-16.4) [18]. The man-biting activity of $S$. damnosum increased in September-December, then decreased in February-June. The highest vector density and monthly biting rates (MBR) were recorded in September $2010(N=1163$ flies, MBR $=6978$ bites/person/month), whereas none were recorded from April to June. The hourly-based distribution of black flies showed a bimodal pattern with two peaks (07:0010:00) and (14:00-18:00) in the Galabat sub-focus [20].

This study was conducted to document the breeding sites of onchocerciasis vector $S$. damnosum s.l. along Atbara River in the Galabat sub-focus, and to investigate the effect of the construction of the dam complex on the size of the sub-focus and the distribution of black fly vectors.

\section{Methods}

\section{Study area}

The Galabat sub-focus is found in eastern Sudan around the Atbara River (N $14^{\circ} 06^{`}-12^{\circ} 57^{`}$, E $\left.35^{\circ} 56^{`}-36^{\circ} 09^{\prime}\right)$ at an altitude range of $540-1040 \mathrm{~m}$ (Fig. 1). The water level at Atbara River increases generally in July to reach its peak in the rainy season from August to October, then decreases rapidly and forms isolated pools from March to May. The coordinates of each site from the first village in the sub-focus "Balashora" at the border with Ethiopia to the last village in the sub-focus "Al Bahkar" had been determined and listed in Additional file 1.

\section{Aquatic stages survey}

During 2009, 2013, and 2015, investigation of 40 Simulium breeding sites were conducted from October and November of each year during the study period (Additional file 1). After its construction in 2015, the area in front of the dam complex was also surveyed for the presence of the vectors.

Aquatic stages (eggs, larvae, and pupae) of black flies were collected from different submerged plants like Digitaria ciliaris, Kanahia laniflora and Cynodon dactylon which are locally known as Dees, Guweer, and Nageela respectively [21]. The collected larvae and pupae were preserved in $80 \%$ ethyl alcohol for morphological identification following the taxonomic keys of Freeman and de Meillon (1953), Crosskey (1962), Davies and Crosskey (1991) [22-24]. 


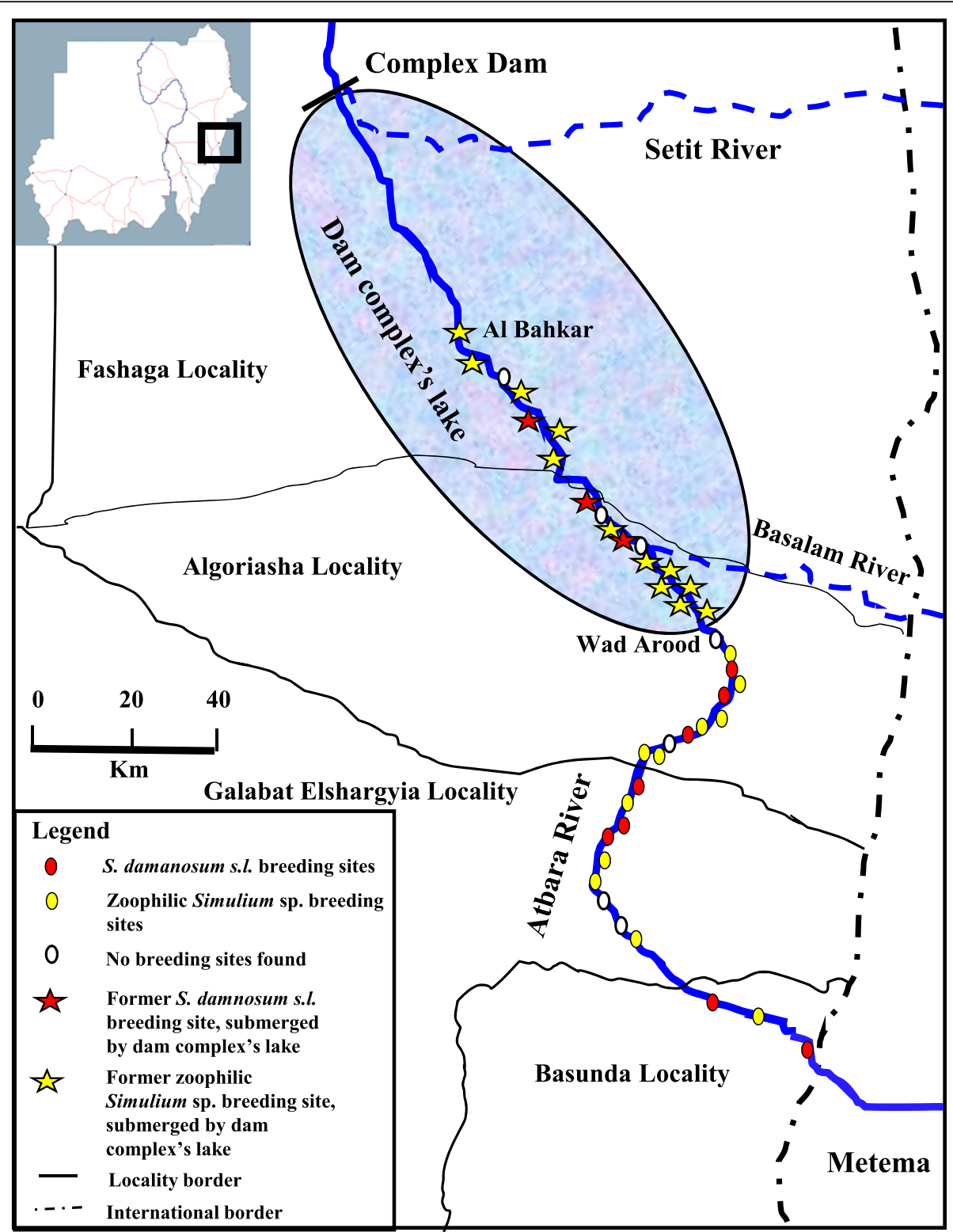

Fig. 1 Map of the Galabat sub-focus showing the study sites before and after the construction of the Upper Atbara and Setit Dam complex

\section{Results}

Aquatic stages of Simulium black flies were collected from 40 breeding sites in the Galabat sub-focus. Details of locations and abundance of breeding sites are described in Additional file 1. Collected samples revealed three species: S. damnosum s.l. and two zoophilic species (S. griseicolle and $S$. adersi). Immature stages of the zoophilic species were predominantly encountered downstream of Atbara River, whereas, the $S$. damnosum s.l. was collected more from upstream of Atbara River where the fast current of water with many rapids was clearly notable.

Before the construction of the dam complex, the first breeding site for onchocerciasis vectors was found in Balashora site near the Ethiopian border [APOC and NPPB:
Annual report of onchocerciasis in Galabat sub-focus/unpublished], and the last breeding site was in Al Bahkar site in north of the focus (Fig. 1). After the construction of the dam complex in 2015, 17 breeding sites located from the dam complex up to Um Gazaz site were totally flooded by water of the dam complex's lake, covering an area of more than $100 \mathrm{~km}^{2}$ (Fig. 1). The 17 flooded sites were previously known as breeding sites of onchocerciasis vectors (Additional file 1). Therefore, the first breeding site was found near Wad Arood site (Fig. 1).

\section{Discussion}

Construction of dams has adverse effects on the physical and biological environment [5, 9, 25]. In this study, 
aquatic stages of Simulium black flies were collected from 40 breeding sites during 2009 and 2013. Clearly, the construction of the Upper Atbara and Setit complex dam in 2015 has reduced the breeding sites of the vectors, as 17 previous breeding sites were covered by flooded water from the dam complex's lake. This resulted in shrinking of the Galabat sub-focus size.

The findings of this study were consistent with previous studies conducted in Ghana [9] and Sudan [5], in which the breeding sites of black flies were reduced due to construction of dams. The chance of disease elimination in the Galabat sub-focus increased when the upper north limit of the sub-focus became a lake.

The identified aquatic stages were revealed to be anthropophilic species (S. damnosum s.l.) and two zoophilic species (S. griseicolle, and S. adersi). They shared same breeding sites, comprised of rocks and vegetation in the Atbara River, but they differed in abundance and distribution alongside the river. Most of S. damnosum s.l. were found upstream of the dam complex (towards the Ethiopian border) where the speed of water was very high and many rapids were found. S. griseicolle and S. adersi predominated downstream of the dam complex where the water current was low. This observation was mentioned early in previous studies $[17,26,27]$.

The presence of high numbers of aquatic stages of $S$. damnosum s.l. at Balashora site, adjacent to the Ethiopian border, may support the idea of considering the Galabat sub-focus in Sudan and the Metema sub-focus in Ethiopia as one transmission zone. This consideration was supported previously by Raybould and White [26] who suggested control measures to be taken by the governments of Sudan and Ethiopia.

The nearest Sudanese focus to the Galabat sub-focus is more than $600 \mathrm{~km}$ at "Khor Yabus," and the chance for new infection or recrudescence will be low if the disease is eliminated from Galabat. This is similar to the isolation of the Abu-Hamed focus after Merowe Dam was built in 2009 [5]. Conscientious monitoring of breeding sites in front of the dam complex is imperative. An agreement between Sudan and Ethiopia is required to eliminate the disease from the one transmission zone in the area.

\section{Conclusions}

Construction of the Upper Atbara and Setit Dam complex and its artificial lake had changed the physical, biological, and socio-economic environment of the affected breeding sites in the Galabat sub-focus. The dam complex has produced a positive effect by reducing the breeding sites of black flies in the area. Agreement on an action plan for an effective disease control/elimination program must be achieved between Sudan and Ethiopia.

\section{Additional file}

Additional file 1: Abundance of aquatic stages of Simulium black fly collected from different sites in Galabat sub-focus, during 2009, 2013 and 2015. (DOCX $26 \mathrm{~kb}$ )

\section{Abbreviations}

CDTI: Community-directed treatment with ivermectin; Cl: Confidence interval; MBR: Monthly biting rate; S: Simulium; s.l: sensu lato

\section{Acknowledgements \\ Thanks are extended to the local communities of the study sites in Galabat sub-focus for their cooperation during the collection of samples. Special thanks to Professor James Fox, Associate Professor of English, Ohio University Zanesville, US, for reviewing and editing the manuscript.}

\section{Authors' contributions}

IMAZ, KH and DAB made substantial contributions to the conception and the design of the study. IMAZ, AE, SGG, AKA, AA, HAS, DMA, OAS, OJO and DAB did the field work. IMAZ, AE, SGG, AKA, AA, HAS, DMA, and DAB did the laboratory work. IMAZ and AE did the analysis and data interpretation. NA and $D A B$ made contribution for survey facility and materials. IMAZ and $A E$ drafted the manuscript. IMAZ, AE, SGG, AKA, AA, HAS, DMA, OAS, OJO, DB, $\mathrm{NA}$ and $\mathrm{KH}$ critically revised the manuscript; all authors read and approved the final manuscript.

\section{Funding}

Not applicable.

\section{Availability of data and materials}

All data generated or analyzed during this study are included in this published article.

\section{Ethics approval and consent to participate}

The study was approved by the community leaders, Gedarif state $\mathrm{MOH}$, and the Federal Ministry of Health, Sudan. Ethical approval for the study was provided by the Federal Ministry of Health, Sudan as a part of the national onchocerciasis elimination/control program.

\section{Consent for publication}

Not applicable.

\section{Competing interests}

The authors declare that they have no competing interests.

\section{Author details}

${ }^{1}$ Onchocerciasis Control/Elimination Programme, National Programme for Prevention of Blindness (NPPB), Federal Ministry of Health, Khartoum, Sudan. ${ }^{2}$ Department of Parasitology and Medical Entomology, Faculty of Medical Laboratory Sciences, University of Khartoum, Khartoum, Sudan. ${ }^{3}$ Department of Immunology and Biotechnology, Tropical Medicine Research Institute, National Center for Research, Khartoum, Sudan. ${ }^{4}$ Department of Medical Entomology, Blue Nile National Institute for Communicable Diseases, University of Gezira, Gezira, Sudan. ${ }^{5}$ Department of Medical Entomology, National Public Health Laboratory, Federal Ministry of Health, Khartoum, Sudan. ${ }^{6}$ Department of Epidemiology, Federal Ministry of Health, Khartoum, Sudan. ${ }^{7}$ Department of Pure and Applied Zoology, Federal University of Agriculture, Abeokuta, Nigeria. ${ }^{8}$ Department of Research and Development, Mission to Save the Helpless (MITOSATH), Jos, Nigeria. ${ }^{9}$ Parasitology Department, Noguchi Memorial Institute for Medical Research, University of Ghana, Accra, Ghana. ${ }^{10}$ The Carter Center, Khartoum, Sudan. ${ }^{11}$ National Programme for Prevention of Blindness (NPPB), Federal Ministry of Health, Khartoum, Sudan.

Received: 11 December 2017 Accepted: 20 May 2019 Published online: 28 May 2019

\section{References}

1. Conniff K, Molden D, Peden D, Awulachew S. Nile water and agriculture: Past, present and future. In: Awulachew S, Smakhtin V, Molden D, Peden D, 
editors. The Nile River basin: Water, agriculture, governance and livelihoods. Abingdon: Routledge - Earthscan; 2012. p. 5-29.

2. Mekonnen Z, Mersha A, Wheeler K. Reservoir filling options assessment for the Great Ethiopian Renaissance Dam (GERD) using a probabilistic approach. The second new Nile conference "New Nile opportunities: Scientific advances towards prosperity in the Eastern Nile Basin", December 8-9, 2014, Addis Ababa, Ethiopia.

3. Sloff C, Omer A, Heynert K, Mohamed Y. Design and modeling of reservoir operation strategies for sediment management. RCEM 2015: 9th Symposium on River, coastal and estuarine morphodynamics, lquitos, Peru, 30 August-3 September 2015.

4. Adeleke M, Sam-Wobo S, Olatunde G, Akinwale O, Ekpo U, Mafiana C. Bioecology of Simulium damnosum Theobald complex along Osun River, Southwest Nigeria. J Rural Trop Pub Hlth. 2011;10:39-43.

5. Zarroug I, Elaagip A, Abuelmaali S, Mohamed H, ElMubarak W, Hashim K, Deran T, Aziz N, Higazi T. The impact of Merowe dam on Simulium hamedense vector of onchocerciasis in Abu-Hamed focus - Northern Sudan. Parasit Vectors. 2014;7:168.

6. Kale O. Onchocerciasis: the burden of disease. Annals Trop Med Parasit. 1998:92:101-15.

7. Hill C, Platt J, Macdonald J. Black flies: biology and public health risk. Purdue Extension, E-251-W, Public Health, Department of Entomology, Purdue University. 2008. https://extension.entm.purdue.edu/publications/E-251.pdf.

8. Ramadan S, Negm A, Smanny M, Helmy A. Environmental impacts of great Ethiopian Renaissance Dam on the Egyptian water resources management and security. The 23rd. international conference on: Environmental protection is a Must, May 11-13, 2013, Alexandria, Egypt.

9. Girmay Y. Assessing the environmental impacts of a hydropower project: the case of Akosombo/Kpong dams in Ghana. M. Sc. thesis. Stockholm: Royal Institute of Technology; 2006

10. Kuzoe F, Hagan K. The control of Simulium damnosum Theobald (Diptera, Simuliidae) in the region of the Volta Dam. Annals Trop Med Parasit. 1967; 61:338-47.

11. Adewale B, Mafe M, Oyerinde J. Infectivity and transmission dynamics of Simulium damnosum s.l. around Owena dam (Ondo state). West Afr J Med. 1999;18:257-60

12. Myburgh E. Factors that influence adult black fly (Diptera: Simuliidae) survival along the Lower Orange River, South Africa. Final report to the Water Research Commission WRC 2002. Report No: 1019/1/03.

13. Babalola O. Ocular onchocerciasis: current management and future prospects. Clinc Ophth. 2011;5:1479-91.

14. Haseeb M, Satti M, Sherif M. Onchocerciasis in the Sudan. Bull. Wld Hlth Org. 1962;27:609-15.

15. Baker R, Abdelnur O. Onchocerciasis in Sudan: the distribution of the disease and its vectors. Trop Med Parasit. 1986;37:341-55.

16. Marr J. Simulium and onchocerciasis in Sudan. Geneva: World Health Organization; 1977; WHO/NBC/77: 657.

17. Baker R, Abedelnur O. The control of the vectors of onchocerciasis. Sudan Med J. 1985;21(Supplement:95-100

18. Higazi T, Zarroug I, Mohamed H, Mubark W, Deran T, Aziz N, et al. Polymerase chain reaction pool screening used to compare prevalence of infective black flies in two onchocerciasis foci in northern Sudan. Am J Trop Med Hyg. 2011;84:753-6.

19. Ghalib H, Mackenzie C, Williams J, Elsheikh H, Kron M. Severe onchocercal dermatitis in Ethiopian border region of Sudan. Ann Trop Med Parasitol. 1987:81:405-19.

20. Zarroug I, Hashim K, Elaagip A, Samy A, Frah E, ElMubarak W, et al. Seasonal variation in biting rates of Simulium damnosum sensu lato, vector of Onchocerca volvulus, in two Sudanese foci. PLoS One. 2016;11(3):e0150309. https://doi.org/10.1371/journal.pone.0150309.

21. Zarroug I, Elaagip A, Mohamed H, Mubarak W, Osman K, Deran T, Aziz N Nugud A. Plants associated with aquatic stages of onchocerciasis vector Simulium damnosum sensu lato in Abu-Hamed and Galabat foci in Sudan. J Public Health Epidemiol. 2013;5(2):83-6.

22. Freeman $\mathrm{P}$, de Meillon B. Simuliidae of the Ethiopian Region. London and Beccles: William Clowes and Sons Limited; 1953. p. 1-224.

23. Crosskey R. The identification of the larvae of Africa Simulium. Bull World Health Organ. 1962;27:483-9.

24. Davies J, Crosskey R. Simulium vectors of onchocerciasis. Geneva: World Health Organization; 1991; WHONBC/91.992.

25. Myburgh E, Nevill E. Review of black fly (Diptera: Simuliidae) control in South Africa. Onderstepoort J Veter Res. 2003;70:307-17.
26. Raybould J, White G. The distribution, bionomics and control of onchocerciasis vectors in eastern Africa and Yemen, with special reference to Simulium neavei group. Trop Med Parasit. 1979;30:505-47.

27. Baker R, Mustafa M, Abdelnur O. The current status of Simulium species in the Sudan with special reference to onchocerciasis. Sudan Med J. 1985; 21(Supplement:19-27.

\section{Publisher's Note}

Springer Nature remains neutral with regard to jurisdictional claims in published maps and institutional affiliations.
Ready to submit your research? Choose BMC and benefit from:

- fast, convenient online submission

- thorough peer review by experienced researchers in your field

- rapid publication on acceptance

- support for research data, including large and complex data types

- gold Open Access which fosters wider collaboration and increased citations

- maximum visibility for your research: over $100 \mathrm{M}$ website views per year

At BMC, research is always in progress.

Learn more biomedcentral.com/submissions 